\title{
Banks Efficiency and the Determinants of Non-Performing Financing of Full-Fledged Islamic Banks in Indonesia
}

\author{
Chandra Setiawan and Selly Magdalena Sherwin
}

\begin{abstract}
This paper investigates the efficiency of Indonesian Full-fledged Islamic Banks by employing Data Envelopment Analysis (DEA) approach; the determinants of non-performing financing (NPF) during the period 2012(Q1) to 2016(Q2) by using Panel Least Square for fixed effect model; the inter-temporal relationships between banks efficiency and NPF are run using VAR model to test the two hypotheses: "Bad Debt" and "Bad Management". This research uses quarterly published reports data of Central Bank of Indonesia (Bank Indonesia) and Financial Service Authority of Indonesia (Otoritas Jasa Keuangan Indonesia) with 4 Islamic banks as the sample of research. The overall results show that Exchange rate, Return on Asset Ratio (ROA), Financing to Deposit Ratio (FDR), Size have a negative and significant effect on NPF, while $B$ l rate have a positive and significant effect on NPF. The finding of DEA indicates the mean score of Fullfledged Islamic banks in Indonesia is approach to efficient with the score $96.54 \%$ and Bank Rakyat Indonesia Syariah (BRIS) is the most technical efficient. The result shows that Full-fledged Islamic banks in Indonesia is not support the "bad management" and "Bad Luck" hypothesis, probably the averagely NPF of full-fledged is $4.5 \%$ that is still bellow of the critical standard of Bank Indonesia.
\end{abstract}

Keyword: Non-performing Financing, Technical Efficiency, Panel Least Square, Data Envelopment Analysis, „Bad Luck", „Bad Management”.

\section{Introduction}

The Indonesian economy, now entering a period of the tough times (Kalla, Jusuf 2016). In Bank of Indonesia statistics stated that economic growth in 2015 did not show good results. Indonesia's economic growth slowed, in the figure of $4.71 \%$ in the 1 st quarter 2015 and $4.67 \%$ in the second quarter, below the target of 5.4\% - 5.8\% growth.

Bank is a financial institution whose operates to collect funds from the public in the form of deposits or saving and then channeled back to the people and provided other banking services. There are two types of banking itself, they are conventional banking and Islamic banking, Islamic banking is a bank that implemented Islamic law and each of the banking sector has their own trend in the market (Kashmir, 2008: 2). Under Article four (4) of Law No. 10 of 1998 which defines, banks in Indonesia acting to support the implementation of national development in order to enhance the equity, economic growth and domestic stability towards increasing the welfare of the people".

Islamic banking until today keeps on encountering a significant increase. It can be seen from the expanding number of Sharia bank office in Indonesia, which reached the level of $179 \%$ improvement from the total asset in 2010 (BI, 2015). However the high development is trailed by the increasing of the credit risk in the past four years as

Dr. Drs. Chandra Setiawan, M.M., Ph.D., Management Study Program, Faculty of Business, President University, Indonesia, E-mail: chandra@president.ac.id Selly Magdalena Sherwin, Management Study Program, Faculty of Business, President University, Indonesia, E-mail: Sherwinselly@gmail.com 
reflected by Non - Performing Financing (NPF) and this ratio getting closer to $5 \%$, which is the maximum permitted from Bank Indonesia (BI) stated in full Regulation of Bank Indonesia No.

6/9/PBI/2004/2004, as depicts in the Table 1.1 bellow.

Table 1: NPF Ratio of Islamic Banks and Islamic Business Unit (Jan 2012 - June 2015)

\begin{tabular}{|c|c|c|c|c|c|}
\hline & 2012 & 2013 & 2014 & 2015 & 2016 \\
\hline Jan & $2.68 \%$ & $2.49 \%$ & $3.01 \%$ & $4.87 \%$ & $5,46 \%$ \\
\hline Feb & $2.82 \%$ & $2.72 \%$ & $3.53 \%$ & $5.10 \%$ & $5,59 \%$ \\
\cline { 2 - 6 } Mar & $2.76 \%$ & $2.75 \%$ & $3.22 \%$ & $5,49 \%$ & $5,35 \%$ \\
\hline Apr & $2.85 \%$ & $2.85 \%$ & $3.49 \%$ & $5,20 \%$ & $5,48 \%$ \\
\hline May & $2.93 \%$ & $2.92 \%$ & $4.02 \%$ & $5,44 \%$ & $6,17 \%$ \\
\hline June & $2.88 \%$ & $2.64 \%$ & $3.90 \%$ & $5,09 \%$ & $5,68 \%$ \\
\hline July & $2.92 \%$ & $3.01 \%$ & $4.30 \%$ & $5,30 \%$ & \\
\hline Augt & $2.78 \%$ & $2.80 \%$ & $4.58 \%$ & $5,30 \%$ & \\
\hline Sep & $2.74 \%$ & $2.96 \%$ & $4.67 \%$ & $5,14 \%$ & \\
\hline Oct & $2.58 \%$ & $2.62 \%$ & $4.75 \%$ & $5,16 \%$ & \\
\cline { 2 - 6 } Nov & $2.50 \%$ & $3.08 \%$ & $4.86 \%$ & $5,13 \%$ & \\
\hline Des & $2.22 \%$ & $2.62 \%$ & $4.33 \%$ & $4,84 \%$ & \\
\hline
\end{tabular}

Source: Islamic Bank Statistics published by Bank of Indonesia

Non-Performing Financing (NPF) is also a financial ratio related to credit risk. Credit risk is the risk of potential misfortunes resulting from the non-settlement of bank loans back banks to borrowers and different counterparties (Ali, 2006: 27). Bank credit risk can be communicated by the number of bad loans or non-performing loans (NPL) in conventional banks and Non-Performing Financing (NPF) in Islamic banks. The higher the value of NPL or NPF of the banks, means implies the higher the credit risk of the bank. According to Ascarya and Yumanita (2009), the instability of a financial system described by the occurrence of three things and one of them was the failure of banking in which banks endured tremendous losses due to falling apart level of NPL.

Most banks in Indonesia still depend on credit as a noteworthy income to fund its operations. According to Siamat (2005), one of the reasons of the grouping of banking business in loaning is the way of business of banks as intermediary institutions between surplus spending units to the deficit spending units and the fundamental source of bank funding comes from the community so they ought to be directed back to the community in the form of credit.

The Islamic bank condition is still in the early improvement and has no incorporation rate yet to the worldwide finance system, so Islamic bank is out of the direct crisis. By the information, the determinant of the NPF can be more originates from the internal factor of the banks, but for making the overall result of this research, the researcher also gives the external factor to be the determinant of NPF. External influences incorporate macroeconomic factors that framed over monetary policy and fiscal policy at the macro level by the State Government (Auliani, 2016).

One critical part of performance estimation is the efficiency of the banking, among others (Sutawijaya and Lester, 2009: 51). So, besides NPF one of the essential parts of determining the performance of the banks is efficiency. Bank efficiency as measured 
through overall technical efficiency (OTE), pure technical efficiency (PTE) and scale efficiency (SE) are important to be controlled and inspected as well as the risks in a particular condition of the economy. Measurement efficiency Banks in this study will use non-parametric Data Envelopment Analysis (DEA).

This study will assess the determinants of NPF from internal and external factors and the relationship of NPF and bank technical efficiency. Before its regression, the researchers measure bank efficiency through data envelopment analysis that ascertains the usage of inputs to produce multiple outputs. Bank efficiency and NPF are vital aspects of measuring banking performance. In several previous studies, Setiawan and Putri (2013) stated that the increase of non-performing financing of the Islamic banks in Indonesia is mainly caused by poor management rather than external factors. The bank-specific variables/internal variables that have more effect to NPF of Islamic banks in Indonesia compared to external variables may also be explained due to the small market share of Islamic banks' assets in Indonesia, just around 3\% compared to conventional banks' total assets. Havidz and Setiawan (2015) stated that regarding the determinants of NPF, there are significant effects of size, operational efficiency ratio (OER), and GDP growth rate toward NPF, while return on assets $(R O A)$, financing to deposit ratio (FDR), capital adequacy ratio (CAR), and inflation rate (INF) have insignificant effect on NPF. On the other hand, the study of Kurniawan (2014) defined that CAR, BI Rate, and OER partially no significant effect on the level of credit risk (NPL), LDR has partially significant effect on the degree of credit risk (NPL) while the ROA has a partial significant negative impact on the level of credit risk (NPL).

This study focus to determine the significant variables that affect the non-performing financing of full-fledged Islamic Banks in Indonesia and to examine the technical efficiency of Full-fledged Islamic Banks in Indonesia by using Islamic Bank's inputsoutputs. This research additionally aimed to determine the inter-temporal relationships between non-performing financing and technical efficiency of full-fledged Islamic Banks in Indonesia.

This paper is structured as follows. Section 2 reviews the literature. Section 3 describes the data and methodology of this study. The empirical results are available in section 4. Finally, we conclude in section 5.

\section{Literature Review}

The researchers reviewed the previous research related to non-performing loans (NPL) in conventional banks and non-performing financing (NPF) in Islamic banks and efficiency of the banking system in full-fledged Islamic banking to arrive at the theoretical framework of this research.

\subsection{Non-Performing Financing Determinants}

Factors that effect NPF can be arrived from internal and external factors. In order to find the causes, external factors used in this research are BI rate and exchange rate. Internal factors considered are Financing to Deposit Ratio (FDR), Bank Size and Return on Asset Ratio (ROA). Several studies which investigate the NPF determinants are Fajriati

(2016), Anin Diyanti (2012), M. Sabir (2012), Kurniawan (2014), Mares Suci (2013), Febrianti (2014), Wikutama (2010). 
Anin Diyanti (2012) and Indah Fajriati (2015) found that FDR has a positive and significant impact on NPF. FDR is a ratio that measures a bank's capacity to meet financial commitments that must fill, therefore, when FDR growth rate increases, gives an indication of the small capacity of the relevant bank liquidity and, therefore, the NPF ratio increases.

M. Sabir (2012) and Kurniawan (2014) found that ROA has a negative and significant effect on NPL ratio. The greater the ROA of a bank, the higher the rate of profit achieved by the bank, the better the position of the bank concerning asset utilization. The profits obtained can be used to cover non-performing loans (NPL) incurred (Pramudita, 2013).

According to Mares Suci (2013), Bank Size has a significant and negative effect on NPF. The greater the assets owned by the bank can enhance the volume of financing that can be distributed by the bank, which means that more of the total funding provided. The greater the total funding will lead to the smaller of NPF ratio is generated.

According to Febrianti (2014) found that BI rate has a positive and significant impact on NPF. $\mathrm{BI}$ Rate as a policy that reflects the attitude or stance of the monetary policy set by Bank Indonesia and announced to the public. BI Rate in Islamic banking acts as a comparison. Debtors will tend to seek lower interest when making a loan, the current interest rate of conventional bank loans raised due to the increase in the BI rate; the debtors will choose other options that make loans or financing in Islamic banks. In such conditions, the amount of financing provided Islamic banks have increased so that the financing risks faced by Islamic banks also increased.

Based on Wikutama (2010) explains that the depreciation of the home currency has an impact on lending in foreign currency due to the rising borrowing relative value in agreement with the decline of the home currency. Increasing the number of liabilities will result in a decrease in the ability of borrowers to complete the loan, and in many cases led to increasing NPL.

\subsection{Bank Efficiency}

M. D. Huri and Indah Susilowati (2004) explains that efficiency can be explained as the ratio between the output (output) to the input (input), or the amount of output generated from one input used. Shakir Ahmad Kurnia (2004) explains that the overall banking efficiency can be decomposed inefficiencies of scale (scale efficiency), the efficiency of coverage (scope efficiency), technical efficiency (technical efficiency), and the efficiency of the allocation (allocative efficiency).

Nurul Komaryatin (2006) mentioned there are two terms of efficiency, the technical and economic efficiency. Economic efficiency has a macro point of view that has more reach than technical efficiency micro-view angle. Measurement of technical efficiency tends to be limited to technical and operational relationships in the process of converting inputs into outputs. As a result, the efforts to improve the technical efficiency required a micro policy that is internal, which is the control and optimal resource allocation. Price in economic efficiency cannot consider given because prices influence by macro policy.

Efficiency measurement of Islamic banks in this study will use non-parametric Data Envelopment Analysis (DEA). This method has the advantage of being able to deal with cases of input diverse, as factors that are beyond the control of management and facilitate comparisons of efficiency by using the same criteria. Through the usage of the simple form, ratio is used to determine the efficiency of each organization, including banking institutions (Putri and Lukviarman, 2008: 40).

Some of previous study has been done of analyze about the technical efficiency, the study conducted by Endri (2011) also use DEA for analyze the Performance of Technical Efficiency 
of Regional Development Banks. In addition Slamet Awaludin (2012) do the research about Islamic Banking efficiency analysis approach with data envelopment analysis. Moreover, the research of Wahab, Hosen \& Syafaat Muhari (2014) analyze the comparison between Technical Conventional Commercial Bank and Islamic commercial Banks technical efficiency in Indonesia is used Data Envelopment Analysis also.

Several hypotheses related to the NPF and efficiency, they are "bad management" and "bad luck." The " bad management theory related to the poor management in the banking industry that can be caused the results of poor quality loans, and therefore, escalates the level of nonperforming loans. On the other hand, in "bad luck" hypothesis the increasing of nonperforming loans is caused by an unexpected exogenous event or bad luck, such as the economic slowdown (Berger and De Young, 1997). Past studies of Setiawan and Putri (2013) stated that the increase of non-performing financing of the Islamic banks in Indonesia mainly causes of poor management rather than external factors. In addition, the result of the study conducted by Setiawan and Bhirawa (2016) also has the result that in line with Setiawan and Putri (2013) result. In this study, the researcher will discover whether "bad luck" hypothesis or "bad management" hypothesis applied to Full-Fledged Islamic Banks in Indonesia.

\section{Methodology}

\subsection{Research Questions}

1. What factors both internal and external that provides significant effect and how those factors affect the Non-Performing Financing (NPF) of Full-fledged Islamic Banking in Indonesia?

2. What is the most efficient Full-fledged Islamic Bank in Indonesia from January 2012 until June 2016?

3. What is the inter-temporal relationship between NPF and Full-fledged Islamic bank technical efficiency?

\subsection{Modeling Non-Performing Finance Determinant and Cost Efficiency}

\subsubsection{Estimation of Determinants of Non-Performing Financing}

The application software utilized for analyzing the determinant variables of NPF is Eviews version 9. Eviews gives complex information data analysis, regression, and forecasting equipment. Regression analysis utilized as a part of this study is panel data regression. Data regression method can give more information that will create the most prominent level of flexibility and can conquer the issues occurred when there is precluded variables (Widarjono, 2007).

The application software used in analyzing the determinant factors of NPF is Eviews version 9. Eviews provides sophisticated data analysis, regression, and forecasting tools. Regression analysis used in this research is panel data regression. Panel data regression method can provide more data that will produce the greater degree of freedom and can overcome the problems occurred when there is omitted-variable (Widarjono, 2007). Panel regression model has three option models for the estimation outcomes. Those three models are (1) Common Constant Model (The Pooled OLS Method), (2) Fixed Effect Model (FEM), and Random Effect Model (REM). In order to find the suitable estimation model, Chow test and Hausman test are conducted. However, since the cross section data $(\mathrm{N})$ in this study is lower than the number of independent variables, Hausman test cannot be used. Therefore, the method that will be examined is Common Constant model and Fixed Effect model.

In this research, external and internal factors will be used to find the significant variables that affect NPF of full-fledged Islamic banks. The external factors are represented by BI rate and 
exchange rate. On the other hand, FDR, ROA and Bank Size explain the internal factors. Panel regression of Non Performing Financing (NPF) determinants can be formulated as follows:

Yit $=\alpha i+\beta 1 X i t, 1+\beta 2 X i t, 2+\beta 3 X i t, 3+\beta 4 X i t, 4+\beta 5 X i t, 5+\varepsilon i t$ In which:

$Y=$ Non Performing Financing (NPF) $\alpha=$ constant

$\mathrm{X} 1=\mathrm{Bl}$ rate

$\mathrm{X} 2$ = Exchange rate (growth)

X3 = Financing to Deposit Ratio (FDR)

X4 $=$ Return on Asset Ratio $X 5=$ Bank Size $\beta 1=$ Determines the contribution of $\mathrm{BI}$ rate (Coefficient regression of $\mathrm{BI}$ rate) $\beta 2=$ Determines the contribution of exchange rate (growth) (Coefficient regression of exchange rate (growth)) $\beta 3=$ Determines the contribution of FDR (Coefficient regression of FDR) $\beta 4=$ Determines the contribution of ROA (Coefficient regression of ROA) $\beta 5=$ Determines the contribution of Banks Size (Coefficient regression of Bank Size) $t=$ Total number observations for each bank $\varepsilon=$ Composite error term

The researchers performed t-test to see the effect of each independent variable on the dependent variable by comparing the value of significant $t$ with significant standard ${ }^{\alpha}=0.05$. The hypotheses to be tested are:

$\mathrm{HO}_{1}$ : There is no significant effect of FDR to the NPF in Full - Fledged Islamic Banks.

$\mathrm{H}_{\mathrm{a} 1}$ : There is significant effect of FDR to the NPF in Full-Fledged Islamic Banks.

$\mathrm{HO}_{2}$ : There is no significant effect of ROA to the NPF in Full-Fledged Islamic Banks

$\mathrm{H}_{\mathrm{a} 2}$ : There is significant effect of ROA to the NPF in Full-Fledged Islamic Banks

$\mathrm{HO}_{3}$ : There is no significant effect of SIZE to the NPF in Full-Fledged Islamic Banks.

$\mathrm{H}_{\mathrm{a} 3}$ : There is significant effect of SIZE to the NPF in Full-Fledged Islamic Banks.

$\mathrm{HO}_{4}$ : There is no significant effect of $\mathrm{BI}$ rate to the NPF in Full-Fledged Islamic Banks.

$\mathrm{H}_{a 4}$ : There is significant effect of $\mathrm{BI}$ rate to the NPF in Full-Fledged Islamic Banks.

$\mathrm{H}_{5}$ : There is no significant effect of Exchange rate to the NPF in Full-Fledged Islamic Banks.

:There is significant effect of Exchange rate to the NPF in Full-Fledged Islamic

$\mathrm{H}_{\mathrm{a} 5}$ Banks.

In addition, F-test is applied to test the simultaneous effect of independent variables on the dependent variable. Before the hypothesis test, classical assumption testing is conducted through normality test, heteroscedasticity test, autocorrelation test, and multicollinearity test.

\subsubsection{Estimation of Technical Efficiency}

Bank efficiency as measured through overall technical efficiency (OTE), pure technical efficiency (PTE) and scale efficiency (SE) are important to be controlled and inspected as well as the risks in a particular condition of the economy. Measuring the effectiveness of the bank can be done by some of the methods such as the comparison of the performance indicators of the banking and financial ratios, there are likewise some different technique, the parametric and non-parametric approach (Hadad et al., 2003: 2). The parametric approach incorporates the Stochastic Frontier Approach (SFA), Distribution-Free Approach (DFA), and Thick Frontier Approach (TFA), while the non-parametric approach is to utilize Data Envelopment Analysis (DEA).

In examining the data of efficiency, researchers utilize an application that is DEA - CRS (Data Envelopment Analysis - Constant Return to Scale) output oriented to know the efficiency score. Data Envelopment Analysis (DEA) is a moderately new " data oriented " approach for 
assessing the evaluating the performance an arrangement of associated substances called Decision Making Units (DMUs) which change over many inputs to the different output. DEA utilizes mathematical programming to verifiably appraise the tradeoffs inalienable in the effective experimental frontier (Zhu, 2010:4). In specific, to measure the technical efficiency of Islamic banks, the researchers use the software of Maxdea version 6.13 to run DEACRS (Data Envelopment Analysis - Constant Return to Scale).

In this study, the variables used to calculate technical efficiency are adapted from Endri (2011), Slamet Awaludin (2012) and Abdul Wahab, Muhamad Nadratuzzaman Hosen \& Syafaat Muhari (2014). The variables consist of three kinds of variables to calculate technical efficiency.

Table 2: Variables and Operational Definition of Bank Technical Efficiency

\begin{tabular}{|c|c|c|c|}
\hline Variables & Operational Definition & Scale & Source \\
\hline \multicolumn{4}{|c|}{ Inputs } \\
\hline Total Funds & $\begin{array}{c}\text { Giro Wadhi'ah, mudharabah saving, and } \\
\text { mudharabah deposito }\end{array}$ & Nominal & $\begin{array}{c}\text { Muhamad } \\
\text { Nadratuzzaman } \\
\text { Hosen \& Syafaat } \\
\text { Muhari (2014) }\end{array}$ \\
\hline Labor & $\begin{array}{c}\text { Total expenditures on employees } \\
\text { (Personal Expense) }\end{array}$ & Nominal & $\begin{array}{l}\text { Slamet Awaludin } \\
\text { (2012) }\end{array}$ \\
\hline Fixed Asset & The sum of Physical capital and premises & Nominal & $\begin{array}{l}\text { Muhamad } \\
\text { Nadratuzzaman } \\
\text { Hosen \& Syafaat } \\
\text { Muhari (2014) }\end{array}$ \\
\hline \multicolumn{4}{|c|}{ Outputs } \\
\hline $\begin{array}{c}\text { Total } \\
\text { Financing }\end{array}$ & $\begin{array}{c}\text { Total of financing consist of: murabahah, } \\
\text { mudharabah, musyarakah, istishna, and } \\
\text { qardhul } \\
\text { hasan financing }\end{array}$ & Nominal & $\begin{array}{l}\text { Endri (2011) and } \\
\text { Slamet Awaludin } \\
\text { (2012) }\end{array}$ \\
\hline $\begin{array}{l}\text { Total } \\
\text { Operational } \\
\text { Definition }\end{array}$ & Total of the operational income of the banks & Nominal & Endri (2011) \\
\hline
\end{tabular}

\subsubsection{Inter-temporal Relationship between NPF and Cost Efficiency}

To determine the inter-temporal relationships between non-performing financing (NPF) and bank efficiency of Full-fledged Islamic banks in Indonesia, the researchers utilize Vector Auto Regression (VARs) model for time series in Eviews version 9. As indicated by Schwert User's Guide II (2010), the Vector Auto Regression (VAR) is utilized for determining frameworks of interrelated time series and for dissecting the dynamic effect of random unsettling influence on the system of variables. VAR approach treats every endogenous (independent) variable in the system as a function of the lagged values. This approach has been used by recent studies such as Havidz and Setiawan (2015) and Setiawan and Bhirawa (2016).

The general mathematical representation of a VAR is:

$$
N P F_{I_{n}, t}=f_{1}\left(N P F_{i, t-1} \ldots N P F_{i, t-n} ; e f f_{i, t-1} \ldots e f f_{i, t-n}\right)+e_{i t}
$$




$$
\text { eff } f_{l, t}=f_{2}\left(\text { eff }_{i, t-1} \ldots \text { eff } f_{i, t-n} ; N P F_{i, t-1} \ldots N P F_{i, t-n}\right)+e_{i t}
$$

Where:

$e_{i t}=$ a vector of innovations that may be contemporaneously correlated but are uncorrelated with their own lagged values and uncorrelated with all of the right-hand side variables.

Equation number 1: NPF as dependent variable, cost efficiency as independent variable (Bad Management Hypothesis)

Equation number 2: Cost efficiency as dependent variable, NPF as independent variable (Bad Luck Hypothesis)

\subsection{Data}

This study utilizes secondary data that comprised of quarterly financial ratios of Fullfledged Islamic Banks in Indonesia and macroeconomic indicators that have been published by Bank Indonesia and Central Agency of Statistics / Badan Pusat Statistik. The population of this study is all Islamic banks that operate during 2012Q1 to 2016Q2, which consist of 13 Fulfledged Islamic banks, 24 Islamic business units, and 161 Islamic rural banks.

Sampling technique conveyed in this research is purposive sampling. The first selection determination foundation was the continuous data series example Full-fledged Islamic banks, which publish their quarterly financial report continuously with no out layered data amid the research period. The second selection determination foundation was the banks that have a credit risk problem, or NPF ratio is greater than the threshold set by Bank Indonesia (5\%) amid the period 2012Q1 to 2016Q2. In accordance with these criteria, there are 4 Full-fledged Islamic banks selected as the research sample, which are Bank Rakyat Indonesia Syariah, Bank Syariah Mandiri, Bank Muamalat Indonesia, and Bank Victoria Syariah.

To determine the factors that affect NPF of Islamic banks in Indonesia and to know the model of the data, panel data regression method is applied. Descriptive analysis statistic also used for describing the data by looking at the mean, median, standard deviation, maximum, and minimum. The classic assumption test applied in this research are normality, autocorrelation, multicollinearity, and heteroscedasticity testing. There is two testing methods can be implemented to test the hypothesis which is T-test and F-test. Technical Efficiency is determined by calculating efficiency score through an envelopment model formula. The efficiency score was then regressed against NPF to define the inter-temporal relationships between NPF and bank"s technical efficiency through VAR model for time series.

\section{Results and Discussion}

To find the determinant factors of NPF, Fixed Effect Model is applied as the estimation model due to the result of the Chow test. This research use lagged independent variables. The lagged independent variable strategy is attractive because it indicates to ease the threats to causal identification with-out requiring any other data than that available in the dataset. This approach, in any case, is grounded in a pre-Credibility Revolution understanding of the issue of endogeneity (cf. Angrist and Pischke 2009). The table below is the result of panel data regression using FEM. 
Table 3: Regression Model Result

\begin{tabular}{|c|c|c|c|c|}
\hline \multicolumn{5}{|c|}{$\begin{array}{l}\text { Dependent Variable: NPF } \\
\text { Method: Panel Least Squares } \\
\text { Date: } 11 / 29 / 16 \text { Time: } 14: 31 \\
\text { Sample (adjusted): } 6 / 01 / 20126 / 01 / 2016 \\
\text { Periods included: } 17 \\
\text { Cross-sections included: } 4 \\
\text { Total panel (balanced) observations: } 68 \\
\text { White cross-section standard errors \& covariance (d.f. corrected) }\end{array}$} \\
\hline Variable & Coefficient & Std. Error & t-Statistic & Prob. \\
\hline $\begin{array}{l}\mathrm{FDR}(-1) \\
\mathrm{ROA}(-1)\end{array}$ & $\begin{array}{l}-1.263741 \\
-1.278600\end{array}$ & $\begin{array}{l}0.405732 \\
0.246858\end{array}$ & $\begin{array}{l}-3.114722 \\
-5.179490\end{array}$ & $\begin{array}{l}0.0028 \\
0.0000\end{array}$ \\
\hline $\operatorname{SIZE}(-1)$ & -0.401743 & 0.214238 & -1.875215 & 0.0657 \\
\hline EXCHANGE_RATE(-1) & -0.095083 & 0.052869 & -1.798454 & 0.0772 \\
\hline BI_RATE & 0.629088 & 0.214905 & 2.927280 & 0.0049 \\
\hline C & 4.515582 & 1.972021 & 2.289824 & 0.0256 \\
\hline \multicolumn{5}{|c|}{ Effects Specification } \\
\hline \multicolumn{5}{|c|}{ Cross-section fixed (dummy variables) } \\
\hline R-squared & 0.715502 & Mean dependent var & & 4.586765 \\
\hline Adjusted R-squared & 0.676926 & S.D. dependent var & & 2.156302 \\
\hline S.E. of regression & 1.225632 & Akaike info criterion & & 3.367527 \\
\hline Sum squared resid & 88.62830 & Schwarz criterion & & 3.661285 \\
\hline Log likelihood & -105.4959 & Hannan-Quinn criter. & & 3.483923 \\
\hline F-statistic & 18.54789 & Durbin-Watson stat & & 1.687834 \\
\hline Prob(F-statistic) & 0.000000 & & & \\
\hline
\end{tabular}

The result shows the t-statistic of FDR growth is -3.114 with a significance of 0.0028 . It indicates that FDR has a negative and significant effect on NPF. The result is not in line with the hypothesis and theory. As indicated by Alissanda (2015), this opposing outcome is due to FDR ratio affects bank"s profitability as the opportunity arises to get profit sharing from the total financing, so the profit will be used to cover the NPF. The t-statistic of ROA is 5.179 with a significance level of 0.000 . It indicates that inflation has a negative and significant effect on NPF. This finding is in line with the previous research conducted M. Sabir (2011). Bank Size has the t-statistic is -1.875 with a significant of 0.0657 . It indicates that exchange rate has a negative and significant effect on NPF. This finding agree with Anin Diyanti (2012) and Mares Suci (2013) research result. The t- statistic of Exchange rate is -1.798 with a significant of 0.0772. It indicates that Exchange rate has a negative and significant impact on NPF. This finding is similar with Indah Fajriati (2016). The t-test statistic of BI rate is 2.927 with a significant of 0.0049 . It indicates that $\mathrm{BI}$ rate has a negative and significant impact on NPF. This finding is consistent with Febrianti (2015). The result of the $R^{2}$ of the model is 0.715502 and adjusted $R^{2} 0.676926$. The result of adjusted $R^{2}$ defines that $67.70 \%$ of NPF (dependent variable) is explained by the combination of independent variables which are FDR, ROA, SIZE, 
Exchange rate, and $\mathrm{BI}$ rate. The rest of the $32.30 \%$ are influenced by other factors outside the research model.

\subsection{Cost Efficiency Result}

Based on Data Envelopment Analysis, full-fledged Islamic banks can be technical efficient if the efficiency score is equal to one. Based on Mansyur (2012), Banks with an efficiency value close to 0 , the more inefficient the bank. Meanwhile, banks with efficiency values close to 1 , the more efficient the bank. This study examines the comparative efficiency score of every bank"s sample for every quarter and also the technical efficiency of the specific banks" sample during the period. With a specific end goal to get a comparative result, each bank is arranged successively for every quarter in the software before the program is running. This course of action came about to the relative efficiency score with the benchmark of the most efficient bank in that quarter. Bank Rakyat Indonesia Syariah is has better technical efficient than others bank"s sample period 2012Q1-2015Q2.

This finding indicates the tightening of technical efficiency that BRIS ensured especially the total financing and operational income. Most of the issues lies in total financing and total operational income. But the finding shows BRIS needs to diminish and deal with employee operational and total fixed asset. In addition, the average of NPF of BRIS is the smallest compare others. The another finding shows that the average Islamic banks" cost efficiency during the period 2012Q1-2016Q2 is equal to 96,54\%. It showed that Full-fledged Islamic banks are still not fully efficient in managing its technical and meanly used only $96.54 \%$ of inputs to achieve optimum outputs. This is because the way to manage the financing is still not optimal. Thus, the improvement of cost efficiency is still needed to be emphasized.

\subsection{Vector Auto Regression Model Result}

In order to discover the relationship among NPF and technical efficiency, the researcher will utilize Vector Auto Regression with two, three, four lag. The outcome is exhibited in table 4.12 and 4.13 (the VAR model result can be found in the appendix). Since the effect of the independent variable all in all (with all lag) is of principle interest, the sum of the coefficients are critical (Berger and DeYoung, 1997, pp. 856-857). The program to process VAR model is Eviews version 9.

Table 4 Bad Management Hypothesis

\begin{tabular}{|l|r|r|r|r|r|}
\hline \multicolumn{7}{|c|}{$\begin{array}{c}\text { Dependent: NPF } \\
\text { Sum of } \\
\text { Coefficient }\end{array}$} & $\begin{array}{c}\text { Sum of } \\
\text { Standard } \\
\text { Error }\end{array}$ & $\begin{array}{c}\text { Sum of } \\
\text { tratio }\end{array}$ & $\begin{array}{c}\text { R- } \\
\text { Squared } \\
\text { of NPF }\end{array}$ & $\begin{array}{c}\text { F- } \\
\text { statistic } \\
\text { of NPF }\end{array}$ \\
\hline $\begin{array}{l}\text { EFF LAG } \\
2\end{array}$ & 2,82651 & $-5,43595$ & 0,00000 & 0.588411 & 23,23112 \\
$\begin{array}{l}\text { EFF LAG } \\
3\end{array}$ & 2,52524 & $-8,64992$ & 0,82457 & 0.587597 & 14,72305 \\
\cline { 1 - 1 } $\begin{array}{l}\text { EFF LAG } \\
4\end{array}$ & 2,42265 & $-11,851680$ & 0,7872 & 0.608710 & 11,4729 \\
\hline
\end{tabular}

Source: Data processed by Author with MaxDEA 6.13 program 
Table 5 Bad Luck Hypothesis

\begin{tabular}{|c|c|c|c|c|c|}
\hline \multicolumn{6}{|c|}{ Dependent: EFF } \\
\hline & $\begin{array}{c}\text { Sum of } \\
\text { Coefficient }\end{array}$ & $\begin{array}{l}\text { Sum of } \\
\text { Standard } \\
\text { Error }\end{array}$ & $\begin{array}{l}\text { Sum of } \\
\text { tratio }\end{array}$ & $\begin{array}{c}\text { R- } \\
\text { Squared } \\
\text { of EFF }\end{array}$ & $\begin{array}{l}\text { F-statistic } \\
\text { of EFF }\end{array}$ \\
\hline $\begin{array}{l}\text { NPF LAG } \\
2\end{array}$ & $-0,000356$ & $-0,01152$ & 0 & 0.139626 & 2,63714 \\
\hline $\begin{array}{l}\text { NPF LAG } \\
3\end{array}$ & 0,001229 & $-0,01907$ & $-0,26584$ & 0.183734 & 2,325933 \\
\hline $\begin{array}{l}\text { NPF LAG } \\
4\end{array}$ & 0,001091 & $-0,02745$ & $-0,39731$ & 0.185754 & 1,682457 \\
\hline
\end{tabular}

The positive relationship in table 4 demonstrates the increasing of NPF have a tendency to be trailed by the increasing of bank"s efficiency, higher amounts of credit issue make banks cause banks to increase spending in monitoring working out, and/or selling these financing. The results of this research reject "bad management" hypothesis proposed by Berger and De Young (1997) since the estimated sum of coefficient of NPF lag 4 of full-fledged Islamic banks is associated positively with efficiency.

In addition, at table 5, the outcome shows that the sum of the technical efficiency coefficient is related negatively with Non-Performing Financing. This result rejects the "bad luck" hypothesis which proposed that the decline in measured bank effectiveness is commonly followed by decline non-performing financing.

None of them support bad luck or bad management, since averagely all the banks consider approach to efficient with the mean score 96.54. In addition, the average of NPF is still below the standard which is averagely 4,587. That number of Non-performing financing still below $5 \%$ as the Non-performing financing standard from Bank of Indonesia regulation No. 6/9/PBI/2004/2004. Therefore, the outcome of this study shows that Full-fledged Islamic banks in Indonesia are not support both of the hypothesis which are "bad management" and "Bad Luck" hypotheses. There is no confirmation on a reverse relationship and no significant support for the alternate hypothesis either.

\section{Conclusion}

This study tried to examine the impact of the determinant variables on NPF. NonPerforming Financing is affected by internal and external factors both partially and simultaneously. The internal and external variables are FDR, ROA, SIZE, and Exchange rate that has a negative effect towards Non-performing financing. Meanwhile, BI rate has a positive effect toward Nonperforming.

The average of Full-fledged Islamic banks technical efficiency period 2012Q1 - 2016Q2 is equal to $96,54 \%$. It showed that Full-fledged Islamic banks are still not fully efficient in managing its technical and meanly used only $96.54 \%$ of inputs to achieve optimum outputs. This is because the way to manage the financing is still not optimal. In this research the most efficient bank in period 2012Q2 - 2016Q2 is Bank Rakyat Indonesia Syariah compared with the other banks, which averagely used $98.40 \%$ of inputs to achieve the maximum outputs.

From the result of the inter-temporal relationships between NPF and Technical Efficiency, it defines that Full-fledged Islamic banks in Indonesia period 2012Q1 - 2016Q2 not support 
Proceedings of 12th Asia-Pacific Business Research Conference 27 - 28 February, 2017, Concorde Hotel, Kuala Lumpur, Malaysia ISBN: 978-1-925488-29-6

"Bad luck" and „Bad Management" Hypotheses. Probably because of averagely the percentage of NPF is bellow the critical standard which is $5 \%$ and the score of efficiency is approach to fully efficient.

\section{References}

Ahmad Syakir Kurnia.(2005). Data Envelopment Analysis Untuk Pengukuran Effisiensi. Modul Workshop Alat Analisis Magister IImu Ekonomi dan Studi Pembangunan. UNDIP Semarang.

Ali, Masyhud., (2006). Manajemen Risiko, Strategi Perbankan Dan Dunia Usaha Menghadapi Tantangan Globalisasi Bisnis : PT. Raja Grafindo Persada, Jakarta

Alissanda, D.G. (2015). Pengaruh CAR, BOPO, dan FDR terhadap Non-Performing Finance pada Bank Umum Syariah Tahun 2011-2013. Spesia Unisba

Angrist, Joshua D., and J"orn-Steffen Pischke (2009), Mostly Harmless Econometrics, Princeton: Princeton University Press

Ascarya dan Diana Yumanita. (2009). Formulasi Stabilitas Sistem Keuangan Ganda di Bank Indonesia. Bank Indonesia Working Paper Series II/ 2009, November 2009. Jakarta: Pusat Pendidikan dan Studi Kebanksentralan, Bank Indonesia.

Auliani, M. M. (2016). Analisis Pengaruh Faktor Internal dan Faktor Eksternal Terhadap

Tingkat Pembiayaan Bermasalah Pada Bank Umum Syariah di Indonesia Periode Tahun 2010 2014. Undergraduate thesis, Fakultas Ekonomika dan Bisnis Universitas Diponegoro

Berger, A. N., De Young, R. (1997). "Problem Loans and Cost Efficiency in Commercial Banks", Journal of Banking and Finance, Vol. 21; 1-28

Dahlan Siamat, (2005). Manajemen Lembaga Keuangan. "Kebijakan Moneter dan

Perbankan", Jakarta : Fakultas Ekonomi Universitas Indonesia, First Edition

Diyanti, Anin. (2012). "Analisis Pengaruh Faktor Internal dan Eksternal terhadap terjadinya Non Performing Loan (Studi Kasus pada Bank Umum Konvensional yang Menyediakan Layanan Kredit Pemilikan Rumah Periode 2008 - 2011)". Undergraduate thesis, Semarang :Fakultas Ekonomika dan Bisnis: Universitas Diponegoro

Endri. (2011). Evaluasi Efisiensi Teknis Perbankan Syariah di Indonesia: Aplikasi two-stage data envelopment analysis. Skripsi. STEI Tazkia. Awaludin, Slamet. (2012). Analisis Efisiensi Perbankan Syariah Dengan Pendekatan Data Envelopment Analysis (DEA). Undergraduate thesis, Fakultas Ekonomi Universitas Muhammadiyah Surakarta

Fajriati, Indah, (2016). Analisis Pengaruh Faktor Eksternal dan Internal Terhadap Non Performing Finance (NPF)Perbankan Syariah (2009:I- 2015:5). Undergraduate thesis, Fakultas Ekonomi dan Bisnis Universitas Lampung

Febrianti, Silvia Eka. (2015). Analisis Pengaruh Pertumbuhan GDP, Inflasi, BI Rate dan Nilai

Tukar terhadap Kredit Bermasalah pada Bank Konvensional dan Bank Syariah. Journal. Universitas Brawijaya

Febrianti, Silvia Eka. (2015). Analisis Pengaruh Pertumbuhan GDP, Inflasi, BI Rate dan Nilai

Tukar terhadap Kredit Bermasalah pada Bank Konvensional dan Bank Syariah. Journal. Universitas Brawijaya

Hadad, et al. (2003). Analisis Efisiensi Industri Perbankan Indonesia: Penggunaan Metode Non Paramertik Data Envelopment Analysis . www.bi go id

Havidz S. A. H., Setiawan C. (2015). Bank Efficiency and Non-Performing Financing (NPF) in the Indonesian Islamic Banks. Asian Journal of Economic Modelling, 2015, 3(3):61-79

Huri, M. D. dan Indah Susilowati. 2004. "Pengukuran Efisiensi Relatif Emiten Perbankan dengan Metode Data Envelopment Analysis (DEA) (Studi Kasus: Bank- Bank yang Terdaftar di

Bursa Efek Jakarta Tahun 2002)." Jurnal Dinamika Pembangunan. Vol. 1, No. 2, Desember 2004, Hal. 95-107

Kalla, Jusuf (2016). Kondisi Ekonomi Indonesia, from tribunnews.com:

http://www.tribunnews.com/nasional/2016/06/14/di-hadapan-sby-dan-mantan-menteri-jkakuikondisi-ekonomi-indonesia-saat-ini-sulit 
Proceedings of 12th Asia-Pacific Business Research Conference 27 - 28 February, 2017, Concorde Hotel, Kuala Lumpur, Malaysia ISBN: 978-1-925488-29-6

Kashmir. (2008). Bank dan Lembaga Keuangan Lainnya. Revision Edition 2008. Jakarta: PT. Rajagrafindo Persada

Komaryatin, Nurul. (2006). Analisis Efisiensi Teknis Industri BPR di Eks. Karisidenan Pati. Graduate thesis, Universitas Diponegoro.

Kurniawan, Eki. (2014). Pengaruh LDR, CAR, BI RATE,BOPO DAN ROA Terhadap Tingkat

Risiko Kredit Pada Bank Umum Go Public Di Indonesia. Undergraduate thesis, Fakultas Akuntansi Umrah

Mansyur, Fakhruddin. (2012). Analisis Perbandingan Efisiensi Bank Umum Syariah dan Bank Umum Konvensional di Indonesia Menggunakan Metode Stochastic Frontier Approach (SFA). UIN Sunan Kalijaga

Muh. Sabir. M, Muhammad Ali, Abd. Hamid Habbe (2012). Jurnal Pengaruh Rasio Kesehatan Bank Terhadap Kinerja Keuangan Bank Umum Syariah Dan Bank Konvensional Di Indonesia

Popita, Mares Suci Ana. 2013. Analisis penyebab terjadinya non performing financing pada bank umum syariah di Indonesia. Accounting Analysis Journal. vol 4

Pramudita.(2013). Pengaruh Pengelolaan Modal Kerja Dan Struktur Modal Terhadap

Profitabilitas Perusahaan (Analisis Pada Perusahaan Manufaktur Sektor Aneka Industri Dan

Industri Barang Konsumsi Yang Terdaftar DiBursa Efek Indonesia Periode 2007-2011). Undergraduate thesis, Fakultas Ekonomika Dan BisnisUniversitas Diponegoro,Semarang

Putri, Vicky Rahma dan Niki Lukviarman. (2008). "Pengukuran Kinerja Bank Komersial Dengan Pendekatan Efisiensi : Studi Terhadap Perbankan Go - Public di Indonesia. JAAI. Vol 12 No.1. Hal $37-52$

Schwert, G. W. (2010). Eviews7 User's Guide II. US: Quantitative Micro Software

Setiawan, C., \& Bagaskara, Bhirawa Praditya. (2016). Non-Performing Financing (NPF) and Cost Efficiency of Islamic Banks in Indonesia Period 2012Q1 to 2015Q2. Journal of Emerging Issues in Economics, Finance and Banking (JEIEFB) An Online International Research Journal (ISSN: 2306-367X) 2016 Vol: 5 Issue: 1

Setiawan, C., \& Putri, M. (2013). Non Performing Financing and Bank Efficiency of Islamic

Banks in Indonesia. Journal of Islamic Finance and Business Research Vol. 2 No. 1 September 2013 Issue. Pp. 58-76, 69

Sutawijaya, A. dan Lestari, E. P. (2009). "Efisiensi Teknik Perbankan Indonesia Pasca Krisis

Ekonomi: Sebuah Studi Empiris Penerapan Model DEA." Jurnal Ekonomi Pembangunan. Vol. 10. No. 1. Hal 49-67

Wahab, Hosen \& Syafaat Muhari. (2014). Komparasi Efisiensi Teknis Bank Umum

Konvensional (Buk) dan Bank Umum Syariah (Bus) di Indonesia Dengan Metode Data

Envelopment Analysis (DEA). Al-lqtishad: Vol. VI No. 2

Widarjono, Agus (2007). Ekonometrika: Teori dan Aplikasi Untuk Ekonomi dan Bisnis, edisi kedua. Yogyakarta: Ekonisia FE Universitas Islam Indonesia

Wikutama, A. (2010). Faktor-Faktor yang Mempengaruhi Non Performing Loan Bank Pembangunan Daerah (BPD).Magister thesis: Fakultas Ekonomi Universitas Indonesia.

Zhu, J. (2010). Quantitative Models for Performance Evaluation and Benchmarking: Data

Envelopment Analysiswith Spreadsheet. US: Springer Sience + Business Media, LL 